\title{
Smac mimetics increase cancer cell response to chemotherapeutics in a TNF- $\alpha$-dependent manner
}

\author{
BL Probst ${ }^{1}$, L Liu ${ }^{1}$, V Ramesh ${ }^{1}$, L Li ${ }^{1}$, H Sun ${ }^{1}$, JD Minna ${ }^{2,3,4}$ and L Wang ${ }^{*, 1}$
}

Second mitochondria-derived activator of caspase (Smac) is a mitochondrial protein released into the cytosol during apoptosis. Smac mimetics have recently been touted as a novel therapeutic to induce apoptosis in cancer cells. The ability of Smac mimetics to induce apoptosis in vitro has been shown to be dependent upon both XIAP neutralization and cancer cell autocrine tumor necrosis factor- $\alpha$ (TNF- $\alpha$ ) production. In this study we provide new evidence for the utility of Smac mimetics in combination with conventional chemotherapy agents to exacerbate caspase activation and induce cancer cell death. Furthermore, we find that the combination effect is because of a multifaceted mechanism involving both inhibition of cell proliferation by the chemotherapy agents and an enhanced autocrine TNF- $\alpha$ feedback loop by the Smac mimetic/chemotherapy agent combination. Surprisingly, although genotoxic agents typically induce apoptosis through the mitochondrial intrinsic

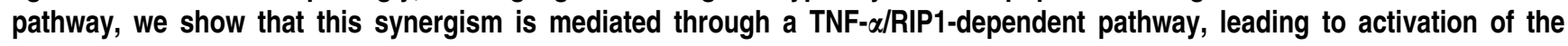
extrinsic apoptotic pathway. Finally, we report that autocrine TNF- $\alpha$ contributes to Smac mimetic-induced tumor regression as a single agent or in combination with chemotherapeutics in xenograft mouse models. Collectively, we provide mechanistic and applicable data to support translational studies in the use of a Smac mimetic/chemotherapy antineoplasm modality.

Cell Death and Differentiation (2010) 17, 1645-1654; doi:10.1038/cdd.2010.44; published online 30 April 2010

Cancer is often the result of a complex paradigm of genetic and epigenetic alterations that results in dysregulated intracellular signaling pathways. The complex and heterogeneous mixture of cells that comprise the tumor mass often limit efficacy of conventional chemotherapy because of intrinsic or acquired drug resistance ${ }^{1}$ or suppression of apoptosis. ${ }^{2}$ Engagement of the apoptotic pathway by modulating pro-apoptotic factors has been proposed as an alternative strategy to trigger cancer cell death., ${ }^{3,4}$

At least two major signaling pathways exist in the induction of apoptosis. The intrinsic cell death pathway involves the permeabilization of mitochondria, resulting in release of proapoptotic factors such as cytochrome $c$ and Smac/Diablo ${ }^{5-7}$ into the cytosol, in which cytochrome $c$ initiates apoptosome formation and activation of caspase- 9 whereas second mitochondria-derived activator of caspase (Smac) relieves the inhibition of caspase by the inhibitors of apoptosis proteins (IAPs). The second apoptotic pathway or extrinsic pathway is initiated through the binding of tumor necrosis factor (TNF) superfamily proteins to their respective cell surface receptors, leading to the activation of caspase- $8 .{ }^{8}$ Activated caspase- 8 and caspase- 9 cleave and activate downstream caspases, including caspases 3 and 7 , which then subsequently cleave their cellular substrates, resulting in apoptosis.

To develop a therapy targeted at abnormalities of apoptosis that have developed in cancer cells, mimetics of Smac were developed as small-molecule antagonists of IAP function to help initiate cancer cell death. Li et al. ${ }^{9}$ first described the efficacy of a dimeric Smac mimetic (compound 3) to potentiate TRAIL and TNF-mediated cancer cell death. Later on, others have developed similar 'smac mimetic' approaches showing activity in various cancer lines. ${ }^{10-13}$ Similar to the endogenous Smac protein, Smac mimetics have been shown to compete with caspases for the binding of $X$-linked inhibitor of apoptosis protein (XIAP)and thereby release the inhibition on caspases imposed by XIAP. ${ }^{9}$ In addition, Smac protein and Smac mimetics induce the proteasomal degradation of cellular inhibitors of apoptosis (clAPs) ${ }^{12-14}$ that promote the release of receptor interacting protein 1 (RIP1) from the TNFRI complex, leading to the formation of RIP1-dependent caspase-8 activation complex..$^{14,15}$ In addition, loss of clAP facilitates the stabilization of NIK, promoting IKK- $\alpha /$ IKK- $\alpha$ activation and NF- $\kappa$ B2 p100 processing to p52. ${ }^{12,13}$ The noncanonical nuclear factor $\kappa$-light-chain-enhancer of activated $\mathrm{B}$ cell (NF- $\kappa \mathrm{B}$ )-driven pathway upregulates specific target genes, including TNF- $\alpha$ that is required, in conjunction with neutralization of XIAP, for Smac mimetic-induced cell death. ${ }^{12-16}$

As Smac mimetics enter clinical trials, it is critical to understand their mode of action as single agents or in combination with conventional chemotherapy to select appropriate patients or treatment regimens. With this intent, a series

\footnotetext{
${ }^{1}$ Joyant Pharmaceuticals Inc., Dallas, TX 75207, USA; ${ }^{2}$ Department of Internal Medicine, University of Texas Southwestern Medical Center at Dallas, Dallas, TX 75390, USA; ${ }^{3}$ Department of Pharmacology, University of Texas Southwestern Medical Center at Dallas, Dallas, TX 75390, USA and ${ }^{4}$ Hamon Center for Therapeutic Oncology, University of Texas Southwestern Medical Center at Dallas, Dallas, TX 75390, USA

*Corresponding author: L Wang, Joyant Pharmaceuticals, 2620 North Stemmons Freeway, Dallas, TX 75207, USA. Tel: + 214267 6006; Fax: 214 267 6007; E-mail: Iwang@joyantpharma.com

Keywords: Smac mimetics; cancer; apoptosis; chemotherapeutics; TNF- $\alpha$

Abbreviations: Smac, second mitochondria-derived activator of caspase; XIAP, X-linked inhibitor of apoptosis protein; cIAP, cellular inhibitor of apoptosis; TNF- $\alpha$, tumor necrosis factor- $\alpha$; RIP1, receptor interacting protein $1 ; \mathrm{NF}-\kappa \mathrm{B}$, nuclear factor $\kappa$-light-chain-enhancer of activated B cells; NSCLC, non-small cell lung cancer; 5 -FU, 5-fluorouracil

Received 23.11.09; revised 25.3.10; accepted 26.3.10; Edited by JP Medema; published online 30.4.10
} 
of cellular and pharmacological studies were used to address their clinical utility. In this study we show that the ability of a small, dimeric Smac mimetic, JP1400, to synergize with conventional cytotoxic agents is dependent on the production of TNF- $\alpha$. Mechanistically, cell death is achieved through a multifaceted process including the inhibition of cellular proliferation and concomitant induction of TNF- $\alpha$ to provide a positive feedback loop, amplifying the TNF receptor-RIP1dependent cell death pathway. Lastly, we provide novel evidence that in vivo treatment of xenograft tumors by Smac mimetics alone or in combination with chemotherapeutics is at least partially dependent on autocrine TNF- $\alpha$.

\section{Results}

Biochemical activity of dimeric Smac mimetic, JP1400. A small-molecular-weight dimeric Smac mimetic, JP1400, was synthesized and its biochemical activity was compared with JP1010, also known as compound 3 by Li et al. ${ }^{9}$ (Figure 1a). Both JP1010 and JP1400 induced degradation of ClAP1, whereas JP1400 showed superior degradation of clAP2 over JP1010 (Figure 1b). In a caspase de-repression assay, JP1400 was slightly better than JP1010 in relieving XIAP-mediated caspase-3 and -9 inhibitions (Figures 1c and d). Given the improved clAP2 activity of JP1400, it was selected for further studies.

Effects of JP1400/chemotherapy agent combinations in a variety of tumor cell lines. A screen of 50 non-small cell lung cancer cell (NSCLC) lines revealed that only $10-20 \%$ of NSCLC lines tested were sensitive to Smac mimetics as a single agent. ${ }^{15}$ This low response rate could limit the usage of Smac mimetics as cancer therapeutics. We asked whether co-treatment with standard chemotherapy agents could render sensitivity to JP1400 in these Smac mimetic singleagent-resistant cells. In all, 10 different cancer cell lines, which are not sensitive to JP1400 single-agent treatment, were chosen for this purpose. The synergy between JP1400 and six chemotherapy agents, including gemcitabine, cisplatin, SN38, paclitaxel, 5-fluorouracil (5-FU) and<smiles>CN[C@@H](C)C(=O)N[C@H](C(=O)N1CCC[C@H]1Cn1nnnc1Sc1ccccc1)[C@@H](C)OCC#CC#CCO[C@H](C)[C@H](NC(=O)[C@H](Cl)NC)C(=O)N1CCCC1Cn1nnnc1Sc1ccccc1</smiles>

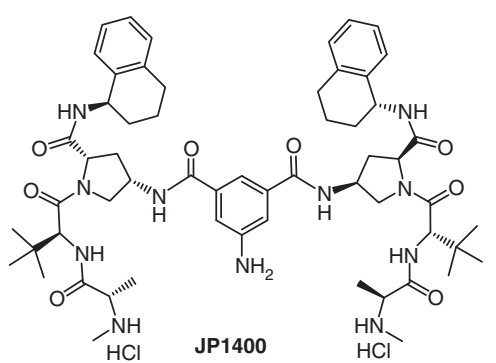

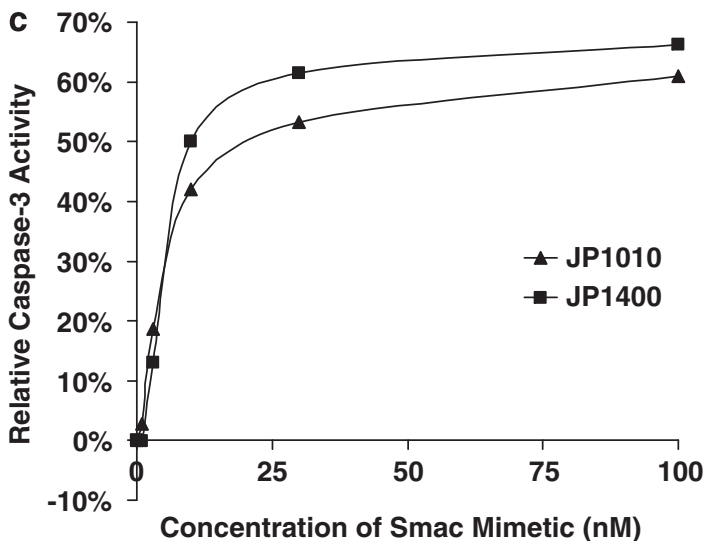

b
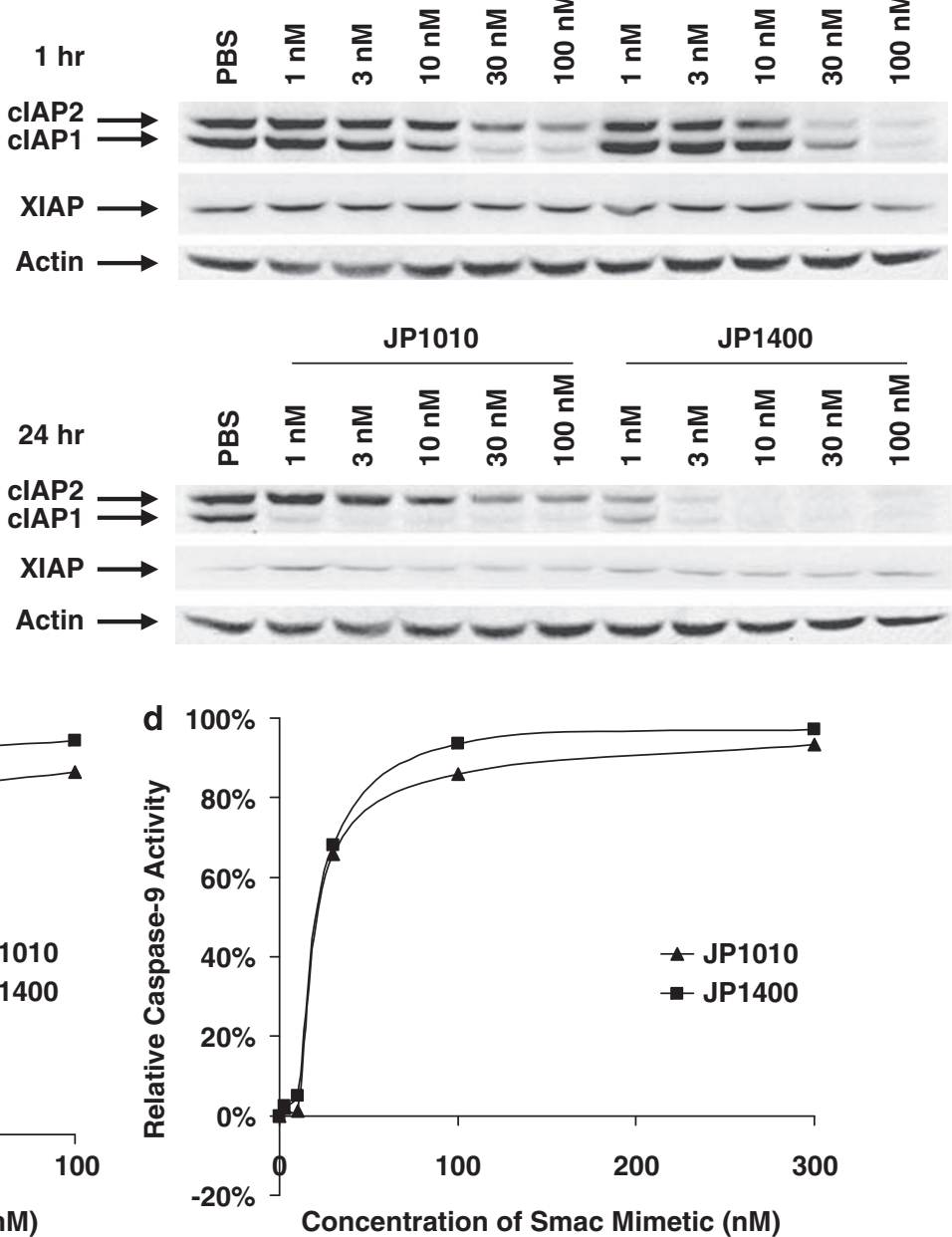

Figure 1 Comparison of JP1010 with JP1400 in ClAP and XIAP activities. (a) Chemical structures of JP1010 and JP1400. (b) Panc-1 cells were treated with increasing concentration of JP1010 or JP1400 for 1 or $24 \mathrm{~h}$. The levels of cIAP1, CIAP2 and XIAP were determined by western blot analysis. (c) Caspase-3 de-repression assay and (d) caspase-9 de-repression assay were carried out as described in the Materials and Methods. Experiments were repeated three times with similar results 
etoposide, was tested. ${ }^{1 C_{50}}$ 's were decreased by at least threefold in the presence of $100 \mathrm{nM}$ JP1400 for at least two of the six drugs in the following five cell lines: A2058, MDA-MB435, HT-29, Miapaca-2 and Panc-1 (Table 1). The cell death response in A2058 cells are shown as examples in Supplementary Figure S1. For future reference, these lines were labeled as 'sensitive' whereas the remaining five cell lines were labeled as 'resistant'.

Chemotherapy agents, but not JP1400, inhibit cell proliferation. To investigate the mechanism by which the chemotherapy agent/Smac mimetic combination induced cell death, cell viability and proliferation assays were performed. JP1400 slightly increased A2058 cell BrdU incorporation, whereas TNF- $\alpha$ had almost no effect on BrdU incorporation, suggesting that neither inhibits cell proliferation (Figure 2a). The combination of TNF- $\alpha$ and JP1400 decreased BrdU incorporation. However, this effect was blocked by the addition of a pan caspase inhibitor, z-VAD, suggesting that the lower level of BrdU incorporation in these cells was likely because of apoptotic cell death and not antiproliferative effects. This is consistent with its effect on cell survival (Figure $2 b$ ). On the other hand, gemcitabine alone was solely responsible for the antiproliferative effects of the chemotherapeutics/ JP1400 combination (Figure 2a). This observation is not unique to gemcitabine as etoposide, SN38, 5-FU, cisplatin and paclitaxel also blocked incorporation of BrdU in a dosedependent manner, irrespective of the presence or absence of z-VAD (Figure 2c and Supplementary Figure S2).

Chemotherapeutics enhance JP1400-mediated caspase-3 cleavage. The apoptotic dependence of caspase activation for the chemotherapy agent/JP1400 combinations was examined in greater detail with western blots for caspase-3 cleavage. Dose titrations of gemcitabine or etoposide alone had no effect on the cleavage of pro-caspase- 3 at $4 \mathrm{~h}$ (Figure 2d). Evidence of cleaved caspase-3 in combination with JP1400 revealed that this effect was entirely Smac mimetic dependent, as treatment of cells with JP1400 alone produced the same effect. As genotoxics generally require longer periods of time to initiate apoptosis, ${ }^{17}$ we also examined caspase cleavage at $24 \mathrm{~h}$. In combination with JP1400, gemcitabine and etoposide induced a dosedependent increase of caspase-3 cleavage that was substantially higher than treatment with JP1400 alone. This combination effect was also observed for cisplatin and SN38 (Supplementary Figure S3a), and in another JP1400/ chemotherapy agent sensitive cell line, HT-29 cells (Supplementary Figures S3b and c). With the exception of cisplatin at $100 \mu \mathrm{M}$, none of the chemodrugs alone induced significant caspase-3 activation, arguing against a direct mitochondrial role for the enhanced caspase activation by the chemodrugs. These data show that chemotherapy in combination with Smac mimetics can indeed enhance the Smac mimetic-induced apoptotic pathway to increase and accelerate cell death.

Chemotherapy/JP1400 synergism is dependent on autocrine TNF- $\alpha /$ RIP1 pathway. It has been previously shown that the molecular mechanism inherent in

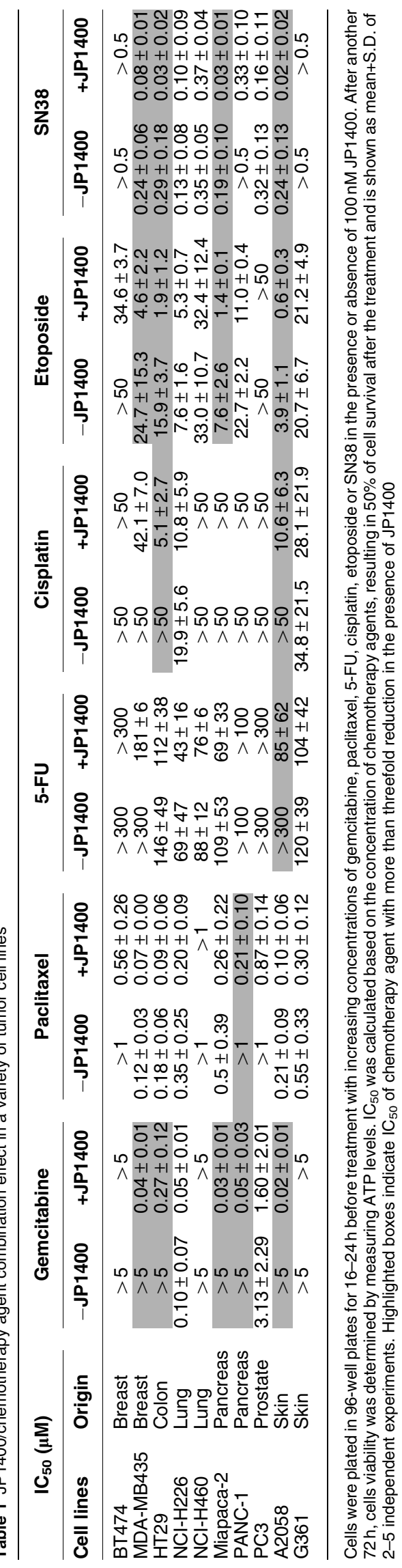



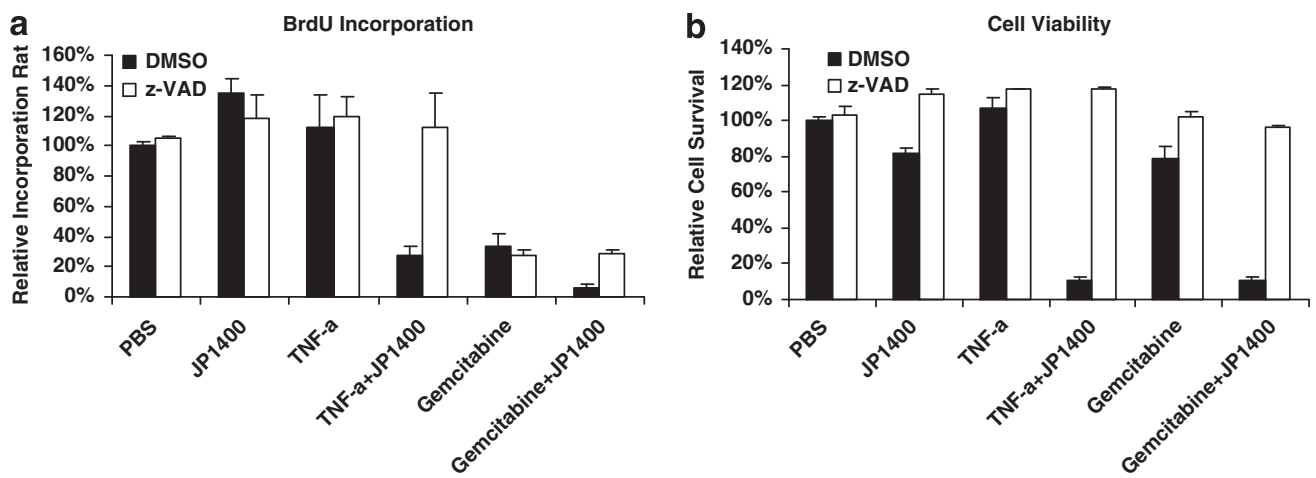

d
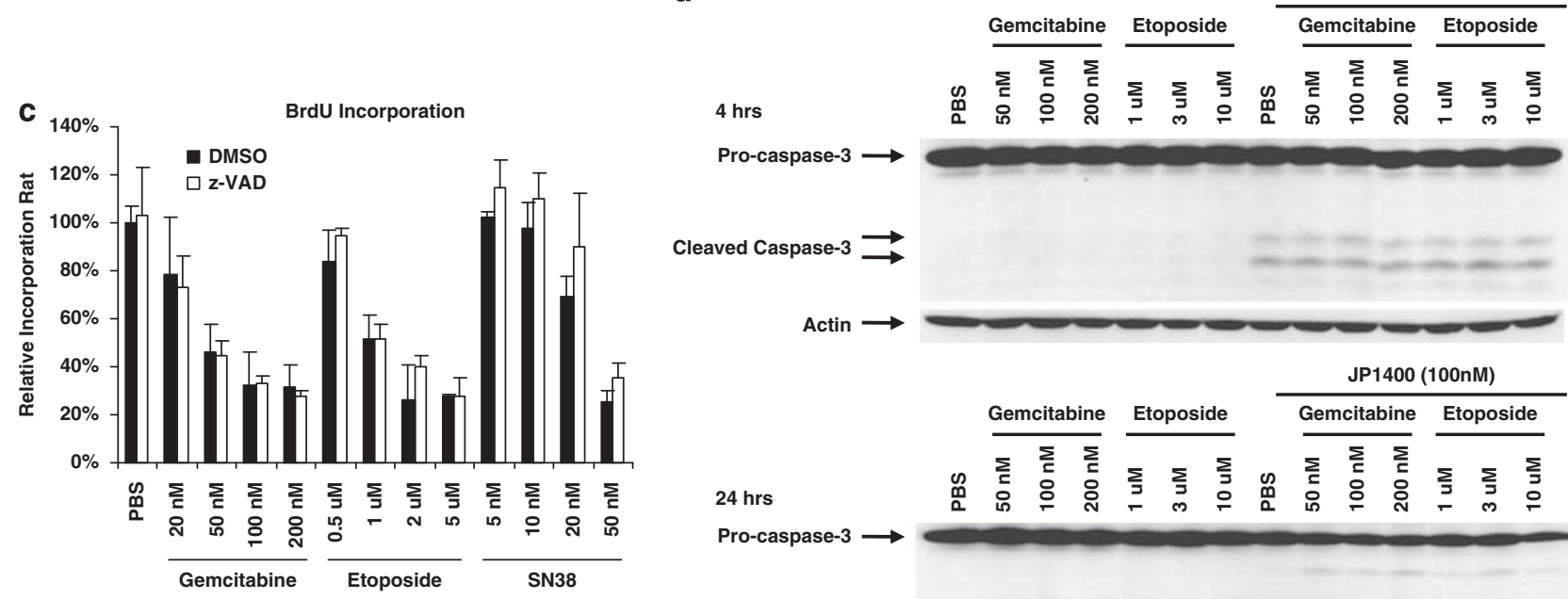

Cleaved Caspase-3 $\longrightarrow$

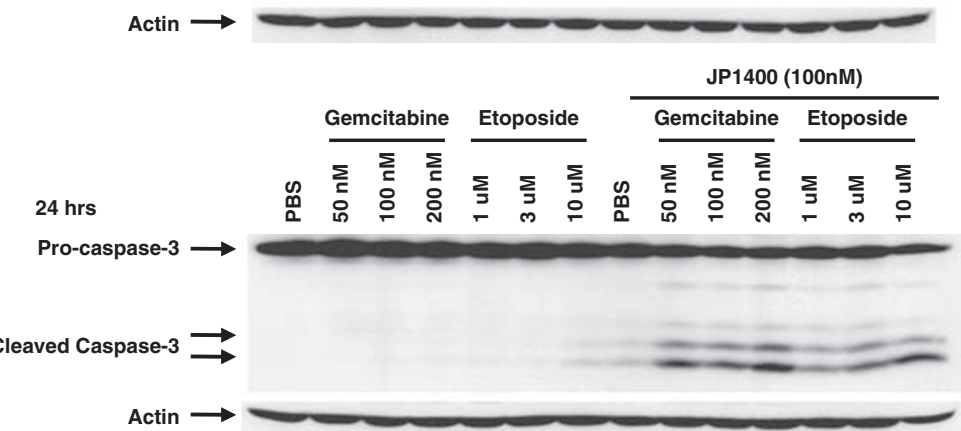

Figure 2 Chemotherapeutics, not JP1400, inhibit cell proliferation. (a) A2058 cells were treated with $100 \mathrm{nM} \mathrm{JP} 1400,100 \mathrm{nM}$ gemcitabine and/or $100 \mathrm{ng} / \mathrm{ml}$ TNF- $\alpha$ for $24 \mathrm{~h}$ in the presence or absence of $20 \mu \mathrm{M}$ z-VAD. Cells were then labeled with BrdU as described in the Materials and Methods. Cell proliferation rate was normalized with that of control samples. (b) A2058 cells were treated as in a for $48 \mathrm{~h}$. Cell viability was determined by measuring ATP levels. (c) A2058 cells were treated with chemotherapy agents at the indicated concentration for $24 \mathrm{~h}$ in the presence or absence of $20 \mu \mathrm{M} \mathrm{z}$-VAD. Cell proliferation rate was determined same as a. Data are presented as mean + S.D. of triplicates. All experiments were repeated three times with similar results. (d) A2058 cells were treated with JP1400 and/or chemotherapy agents at the indicated concentration. Cell lysates were collected after 4 or $24 \mathrm{~h}$. Caspase-3 and actin levels were determined by western blot analysis. Results are representative of two independent experiments

single-agent Smac mimetic sensitivity is dependent upon the presence of autocrine TNF- $\alpha .^{12,13,15}$ Smac mimetics synergize with TNF- $\alpha$ to promote cell death through formation of a RIP1-dependent death-inducing complex. ${ }^{14,15}$ To investigate whether the chemotherapy agent/JP1400dependent cell death was also because of autocrine TNF- $\alpha$ and a RIP1-dependent signaling pathway, cell viability experiments were performed in the presence of neutralizing anti-TNF- $\alpha$ antibody or in the background of RIP1 siRNAknockdown cells. Neutralizing TNF- $\alpha$ antibodies completely blocked the etoposide/JP1400- or SN38/JP1400-induced cell death and partially blocked gemcitabine/JP1400- or cisplatin/JP1400-induced cell death, suggesting that autocrine TNF- $\alpha$ is requisite for its cell killing abilities (Figure 3a). This dependence on autocrine TNF- $\alpha$ was also observed for the combination effect in other cell lines (Supplementary Figure S4, data not shown). In a similar manner, knockdown of RIP1 completely blocked the ability of all four chemotherapeutics to synergize with JP1400 and induce cell death (Figures $3 b$ and $c$ ). We next examined the effect of chemotherapy agents on RIP1-dependent caspase-8activating complex formation. z-VAD was added to prevent the complex from falling apart. ${ }^{15}$ After $24 \mathrm{~h}$ of treatment, JP1400 alone induced significant amount of RIP1/FADD/ caspase-8 complex formation (Figure 3d). Gemcitabine treatment alone had no effect but it enhanced JP1400induced complex formation, suggesting that gemcitabine synergizes with Smac mimetic to activate autocrine-TNF- $\alpha$ signaling.

Induction of TNF- $\alpha$ mRNA levels in response to JP1400 correlates with sensitivity to JP1400/chemotherapy agent combinations. It has been well established that Smac mimetic increases autocrine TNF- $\alpha$ production by inducing clAP1/2 degradation, leading to the stabilization of $\mathrm{NIK}$, and subsequently activation of noncanonical NF- $\kappa \mathrm{B}$ 

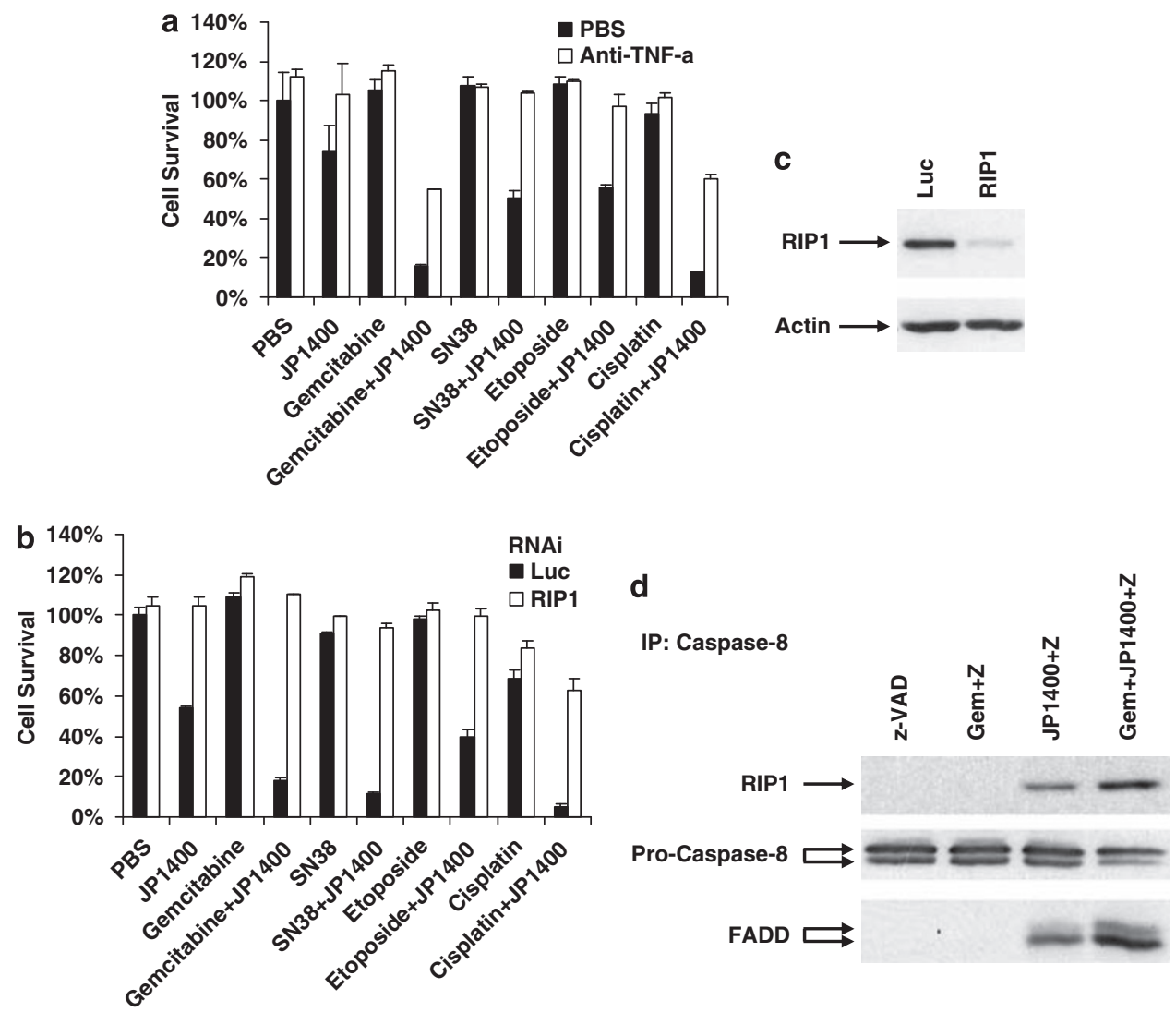

Figure 3 Chemotherapy agent/Smac mimetic synergism acts through autocrine TNF- $\alpha /$ RIP1-dependent pathway. (a) A2058 cells were pretreated with PBS or $5 \mu \mathrm{g} / \mathrm{ml}$ TNF- $\alpha$-neutralizing antibody for $2 \mathrm{~h}$, and then treated with gemcitabine (100 nM), SN38 (50 nM), etoposide (1 $\mu \mathrm{M})$ or cisplatin $(10 \mu \mathrm{M})$ with or without $100 \mathrm{nM} \mathrm{JP1400}$ for $48 \mathrm{~h}$. Cell viability was determined by measuring ATP levels. Data are presented as mean + S.D. of triplicates. (b) A2058 cells were transfected with control luciferase (Luc) siRNA or RIP1 siRNA for $48 \mathrm{~h}$. Cells were then treated with gemcitabine (100 nM), SN38 $(50 \mathrm{nM})$, etoposide $(1 \mu \mathrm{M})$ or cisplatin $(10 \mu \mathrm{M})$ with or without $100 \mathrm{nM}$ JP1400 for $48 \mathrm{~h}$. Cell viability was determined by measuring ATP levels. Data are presented as mean + S.D. of triplicates. (c) Cell lysates were collected $48 \mathrm{~h}$ after transfection and were subjected to western blot analysis of RIP1 and actin levels. (d) A2058 cells were treated with $100 \mathrm{nM}$ gemcitabine and/or $100 \mathrm{nM}$ JP1400 in the presence of $20 \mu \mathrm{M}$ z-VAD for $24 \mathrm{~h}$. Cells were collected and caspase-8 immunoprecipitation was carried out as described in Materials and Methods. The levels of RIP1, caspase-8 and FADD in the immunocomplex were determined by western blot analysis. All experiments were repeated at least two times with similar results

pathway. ${ }^{12,13}$ To further solidify the necessity of TNF- $\alpha$ in chemotherapy/JP1400-induced cell death, the panel of cell lines used in Table 1 was tested for their ability to induce TNF- $\alpha$ mRNA expression in response to JP1400. After $4 \mathrm{~h}$ of treatment, cell lines that showed sensitivity to the chemotherapy agent/JP1400 combination showed three- to eightfold induction of TNF- $\alpha$ over untreated cells, whereas 'resistant' cells showed less than twofold induction (Figure 4a). In contrast, mRNA levels of clAP2, another $\mathrm{NF}-\kappa \mathrm{B}$ target gene, were induced fourfold or more in 9 of 10 cell lines tested (Figure 4b).

Chemotherapy agents such as gemcitabine and cisplatin activate the ATM/ATR DNA-damage signaling pathways leading to ubiquitinylation of IKK- $\gamma / \mathrm{NEMO}$. This in turn releases the IKK- $\alpha / \mathrm{IKK}-\beta$ complex and stimulates the canonical NF- $\kappa$ B pathway through degradation of $\mathrm{I}_{\kappa} \mathrm{B}-\alpha$ and subsequent nuclear translocation of $\mathrm{p} 65$ and Rel $A$ proteins. ${ }^{18}$ Indeed, A2058 cells showed decreased $\mathrm{I}_{\kappa} \mathrm{B}-\alpha$ levels and increased levels of NF- $\kappa$ B p65 in the nucleus after a 24-h treatment with gemcitabine (Figures $4 \mathrm{c}$ and $\mathrm{d}$ ). Consistently, gemcitabine was able to induce TNF- $\alpha$ mRNA levels by 27-fold, which was inhibited by pretreatment of cells with an
IKK inhibitor (Figure 4e). Similar results were obtained with the other chemotherapeutics (data not shown). To investigate whether chemotherapeutics could enhance Smac mimeticinduced TNF- $\alpha$ production, A2058 cells were treated with gemcitabine, etoposide, SN38 or cisplatin in the presence or absence of $100 \mathrm{nM}$ JP1400. Z-VAD was also added to prevent cell death. At $24 \mathrm{~h}$, there was substantial induction of TNF- $\alpha$ by all chemotherapy agents alone, and an even greater synergistic induction was observed in the presence of JP1400. For instance, gemcitabine treatment led to a $\sim 60$-fold induction of TNF- $\alpha$ mRNA, whereas co-treatment with JP1400 boosted that level to over 130-fold (Figure 4f). clAP2 expression was also induced in a similar manner, but to a lesser degree (Figure $4 \mathrm{~g}$ ). z-VAD alone had no affect on TNF- $\alpha$ or clAP2 expression (data not shown). To determine whether TNF- $\alpha$ protein levels correlated with the observed increase in TNF- $\alpha$ mRNA levels, a TNF- $\alpha$ ELISA was used to measure the secreted TNF- $\alpha$ levels in the conditioned cell culture medium. A2058 cells treated with JP1400 led to a twofold increase in TNF- $\alpha$, whereas gemcitabine and the gemcitabine/JP1400 combination produced fourfold and sixfold higher levels of TNF- $\alpha$, respectively (Supplementary 

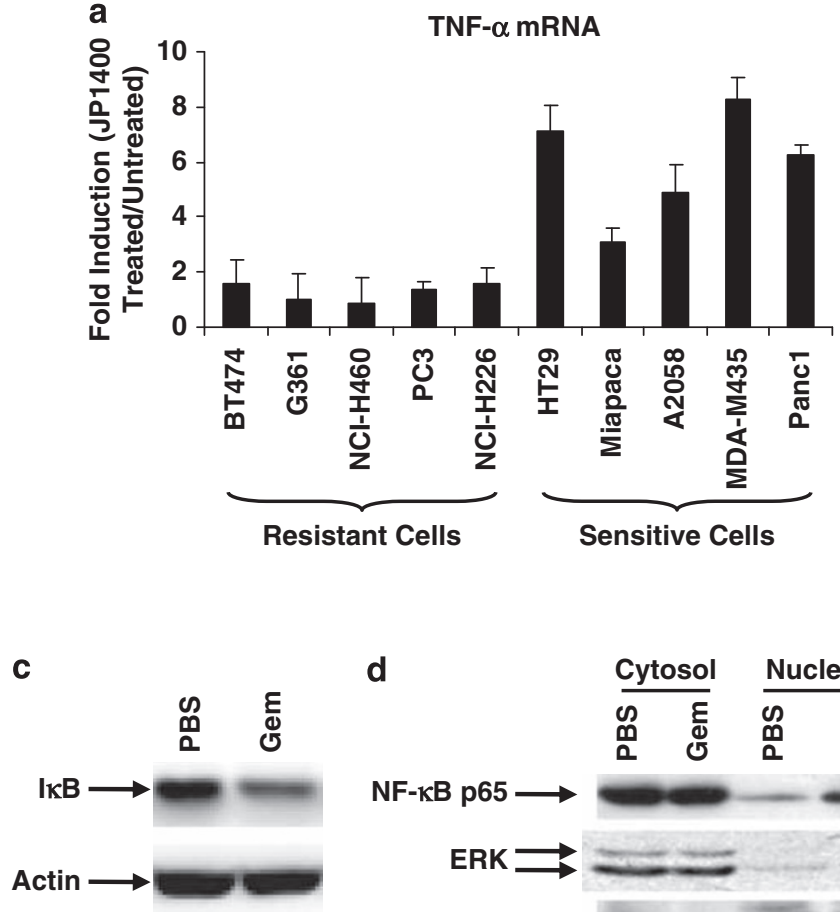

d

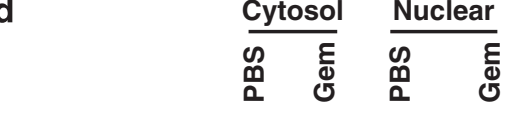

NF-кB p65 $\longrightarrow$

$\mathrm{ERK} \longrightarrow$

Histone $\mathrm{H} 3 \longrightarrow$
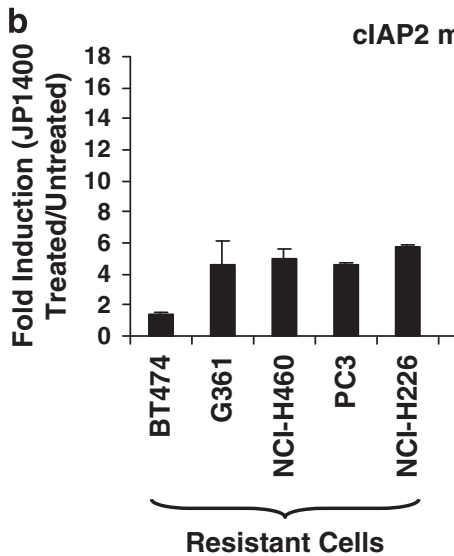

RNA

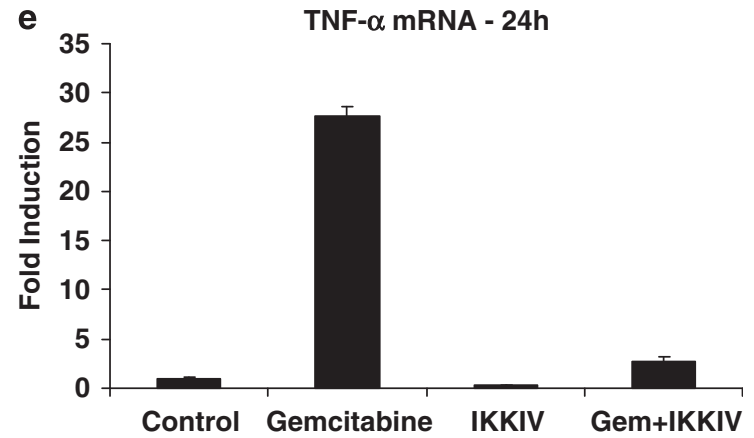

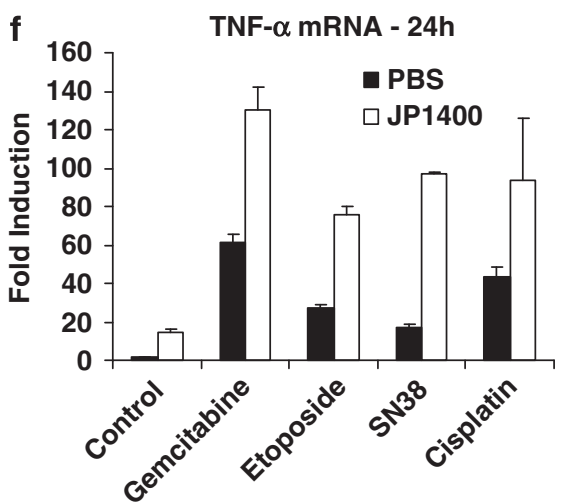

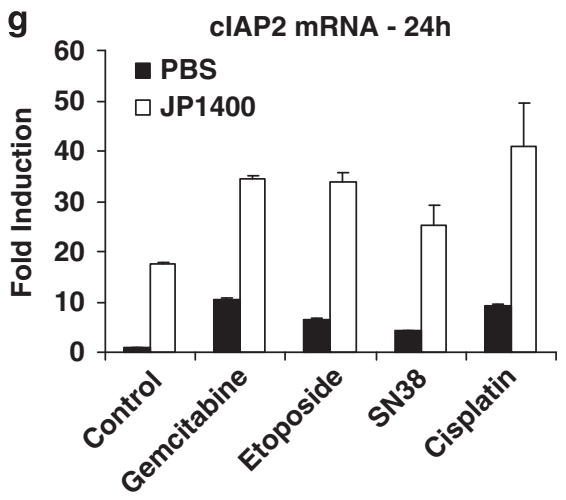

Figure 4 Induction of TNF- $\alpha$ mRNA levels in response to JP1400 correlates with sensitivity to JP1400/chemotherapy agent combinations. (a, b) Cancer cells were treated with $100 \mathrm{nM} \mathrm{JP1400} \mathrm{for} 4 \mathrm{~h}$. Total RNA was extracted and analyzed for TNF- $\alpha$ (a) and CIAP2 (b) expression by real-time PCR. Sample data were normalized to cyclophilin levels and are expressed as fold induction of JP1400-treated cells over untreated cells. Results shown are the average of triplicate measurements + S.D. and are representative of at least two independent experiments. (c) A2058 cells were treated with PBS or $200 \mathrm{nM}$ gemcitabine for $24 \mathrm{~h}$. I $\kappa \mathrm{B}-\alpha$ and actin levels were determined by western blot analysis. (d) A2058 cells were treated with PBS or $200 \mathrm{nM}$ gemcitabine for $24 \mathrm{~h}$. Nuclear and cytosolic fractions were generated as described in Materials and Methods. NF- $\kappa$ B p65, ERK and Histone H3 levels were determined by western blot analysis. (e) A2058 cells were pretreated with PBS or $1 \mu \mathrm{M} \mathrm{IKK} \mathrm{IV} \mathrm{inhibitor} \mathrm{for} 1 \mathrm{~h}$, and then treated with or without $200 \mathrm{nM}$ gemcitabine for $24 \mathrm{~h}$. Total RNA was extracted and analyzed for TNF- $\alpha$ expression by real-time PCR. Sample data were normalized to cyclophilin levels and are expressed as fold induction over untreated cells. Results shown are the average of triplicate measurements + S.D. and are representative of at least two independent experiments. (f, g) A2058 cells were treated with $200 \mathrm{nM}$ gemcitabine, $3 \mu \mathrm{M}$ etoposide, $20 \mathrm{nM}$ SN38 or $30 \mu \mathrm{M}$ cisplatin in the presence of PBS or $100 \mathrm{nM}$ JP1400 in the presence of $20 \mu \mathrm{M} z-V A D$ for $24 \mathrm{~h}$. Total RNA was extracted and analyzed for TNF- $\alpha$ (f) or clAP2 (g) expression by real-time PCR. Sample data were normalized to cyclophilin levels and are expressed as fold induction of treated over untreated cells. Data are presented as mean + S.D. of three independent experiments

Figure S5a). On the other hand, A2058 cells have low endogenous clAP2 protein levels and it is completely eliminated by JP1400 at $24 \mathrm{~h}$ regardless of whether gemcitabine is present (Supplementary Figure S5b).

Autocrine TNF- $\alpha$ contributes to JP1400-induced tumor regression in human tumor xenograft models. Although a 130-fold induction of TNF- $\alpha$ mRNA levels is impressive, these results and those by others have been limited to in vitro systems. To analyze whether Smac mimetic induces tumor autocrine TNF- $\alpha$ production in vivo, we used HCC461 cells, a Smac mimetic single-agent sensitive cell line, in a xenograft model. ${ }^{15}$ Nude mice carrying HCC461 tumors were treated with one single intravenous injection of saline (vehicle) or $3 \mathrm{mg} / \mathrm{kg}$ JP1400. At $6 \mathrm{~h}$ after injection, human TNF- $\alpha$ levels in the plasma were measured through a human-specific TNF- $\alpha$ 
a

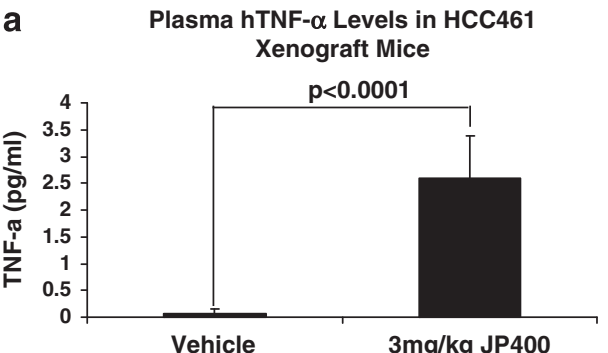

C

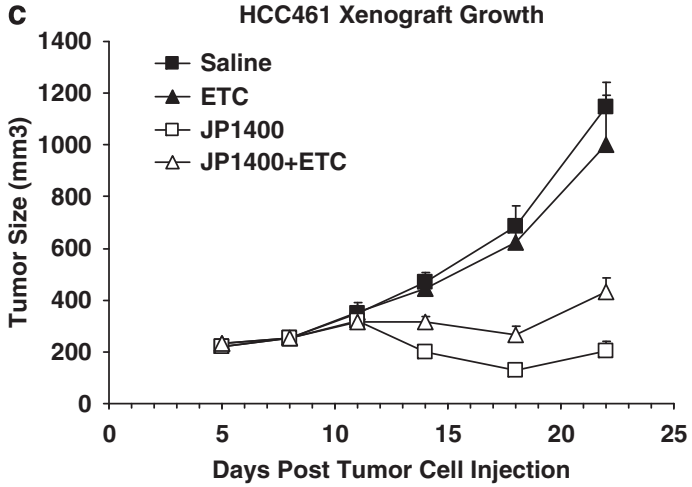

b TNF- $\alpha$ and clAP2 mRNA Levels in HCC461

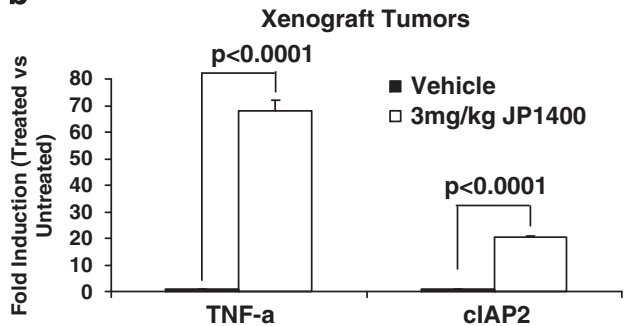

d

\begin{tabular}{|c|c|c|c|}
\hline Group & $\mathbf{n}$ & $\begin{array}{c}\text { Average Tumor } \\
\text { Weight (mg) }\end{array}$ & p Value \\
\hline Saline & 8 & 1146 & \\
\hline ETC & 8 & 1000 & NS. Vs Saline \\
\hline JP1400 & 8 & 203 & k0.0001 vs Saline \\
\hline JP1400+ETC & 8 & 431 & $\begin{array}{c}0.0001 \text { vs Saline; } \\
0.02 \text { vs ETC; } \\
0.007 \text { vs JP1400 }\end{array}$ \\
\hline
\end{tabular}

Figure 5 Autocrine TNF- $\alpha$ contributes to JP1400-induced tumor regression in HCC461 xenograft model. (a, b) HCC461 xenograft mice were i.v. injected with either saline $(n=5)$ or $3 \mathrm{mg} / \mathrm{kg} \mathrm{JP1400}(n=5)$. At $6 \mathrm{~h}$ after treatment, mice were killed and blood and tumor samples were collected. (a) $\mathrm{hTNF}-\alpha$ levels were measured in the plasma using ELISA. (b) Total RNA was extracted from HCC461 tumor samples and analyzed for TNF- $\alpha$ and clAP2 expression by real-time PCR. Sample data were normalized to cyclophilin levels and are expressed as fold induction of JP1400-treated over vehicle-treated samples. Data are presented as mean + S.D. (c, d) HCC461 xenograft mice were treated with $5 \mathrm{mg} / \mathrm{kg}$ of ETC (etanercept) or vehicle (saline) i.p. at days $6,8,11,13$ and 15 after tumor inoculation. JP1400 or vehicle (saline), $1 \mathrm{mg} / \mathrm{kg}$, was i.v. administrated on day 13. Tumor growth curve was shown in $\mathbf{c}$ as mean + S.E.M. and tumor weight at day 22 is shown in $\mathbf{d}$

ELISA (Figure 5a). Mice treated with JP1400 had significant levels of hTNF- $\alpha$ in the circulating plasma, suggesting that in a remarkably short amount of time, Smac mimetics penetrate tumor tissue and trigger the production of TNF- $\alpha$. Similarly, when human TNF- $\alpha$ and clAP2 mRNA levels were evaluated in the excised tumors of HCC461 xenograft mice, we observed an induction of 65 -fold and 20 -fold, respectively $(P<0.0001$; Figure $5 \mathrm{~b})$. These results suggested that the in vivo tumor mimicked our observations in vitro. To provide conclusive evidence for whether TNF- $\alpha$ is required for Smac mimetic sensitivity of whole tumors, $\mathrm{HCC} 461$ xenograft mice were i.p. injected five times with $5 \mathrm{mg} / \mathrm{kg}$ of the soluble TNF receptor, etanercept. Mice were also i.v. injected at day 13 with $1 \mathrm{mg} / \mathrm{kg} \mathrm{JP1400}$. At day 22, saline or etanercept-treated mice had $>1000 \mathrm{mg}$ tumors whereas tumors in JP1400treated mice were only approximately $\sim 200 \mathrm{mg}$ (Figures $5 \mathrm{c}$ and d). Etanercept was only able to partially block JP1400induced tumor cell killing with an average tumor weight of $431 \mathrm{mg}$ at day $22(P=0.007)$.

To ensure that the xenograft response was not unique to HCC461 tumors and that the observations could be translated to combination treatments, an additional cancer cell line, Miapaca-2, was also tested in a xenograft model. Gemcitabine had no effect on tumor cell growth whereas JP1400 alone limited tumor growth to $308 \mathrm{mg}$ compared with $721 \mathrm{mg}$ for saline control $(P=0.004$; Figures $6 \mathrm{a}$ and $\mathrm{c})$. This JP1400 single-agent effect was rather unexpected as JP1400 had minimal effect on Miapaca-2 cells in vitro (Supplementary Figure S6a). The combination of gemcitabine and JP1400 resulted in a twofold decrease in tumor size compared with JP1400 alone $(P=0.03)$, consistent with the in vitro combination effect (Supplementary Figure S6b). Similar to that observed in HCC461 model, treatment of Miapaca-2 xenograft mice with etanercept partially blocked gemcitabine plus JP1400-induced tumor killing $(P=0.002$; Figures $6 b$ and $c)$.

\section{Discussion}

It has been proven that the ability of Smac mimetic to bind $\mathrm{XIAP}$, which releases its inhibition on caspases, as well as to induce cIAP degradation through proteasomal pathway, are both essential for its cell killing activities ${ }^{12-16}$ (Figure 6d). However, these anti-IAP functions cannot be used to predict the cell death response, because in all cell lines tested, regardless of their cell death response, Smac mimetic binds to XIAP and induces cIAP degradation (data not shown). There are two cellular events that result from clAP degradation: (1) activation of the noncanonical NF- $\kappa \mathrm{B}$ pathway and subsequently increased production of autocrine TNF- $\alpha$ and (2) release of RIP1 from the TNF- $\alpha$ receptor complex, leading to caspase- 8 activation, which requires TNF- $\alpha$ receptor to be activated in the first place. Accumulating evidence suggest that whether or not Smac mimetic induces autocrine TNF- $\alpha$ production is the key factor in deciding the cell's fate upon Smac mimetic treatment. Depending on their response to Smac mimetics, cells can be grouped into three general classes: in class I cells, Smac mimetic induces autocrine 

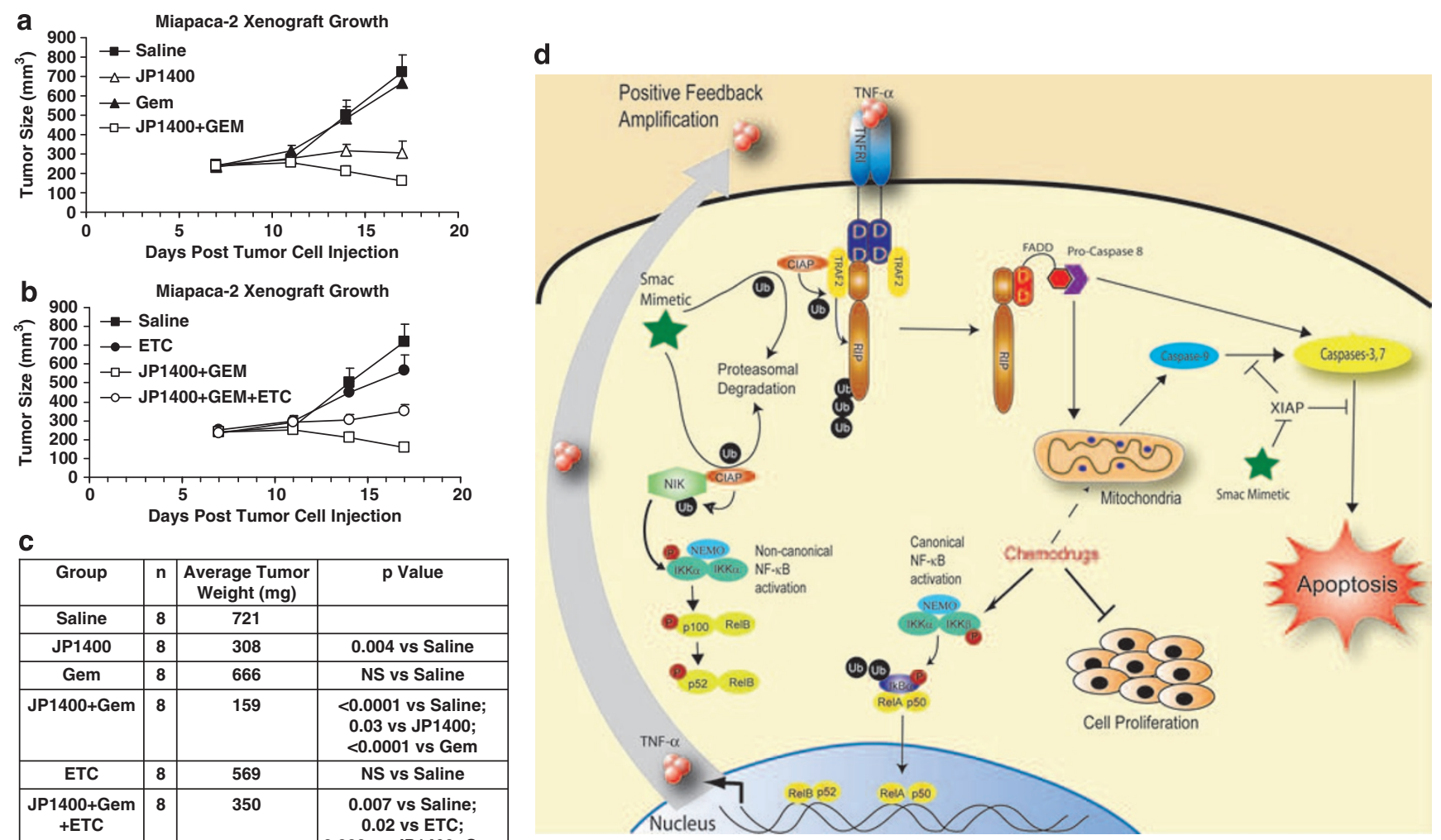

C
\begin{tabular}{|c|c|c|c|}
\hline Group & $\mathbf{n}$ & $\begin{array}{c}\text { Average Tumor } \\
\text { Weight }(\mathrm{mg})\end{array}$ & $\mathrm{p}$ Value \\
\hline Saline & 8 & 721 & \\
\hline JP1400 & 8 & 308 & 0.004 vs Saline \\
\hline Gem & 8 & 666 & NS vs Saline \\
\hline JP1400+Gem & 8 & 159 & $<0.0001$ vs Saline; \\
& & & 0.03 vs JP1400; \\
& & & 0.0001 vs Gem \\
\hline ETC & 8 & 569 & NS vs Saline \\
\hline JP1400+Gem & 8 & 350 & 0.007 vs Saline; \\
+ETC & & & 0.02 vs ETC; \\
& & & 0.002 vs JP1400+Gem \\
\hline
\end{tabular}

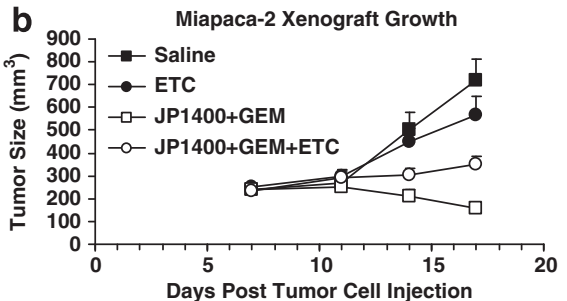

Figure 6 Gemcitabine/JP1400 combination effect in Miapaca-2 xenograft model is partially blocked by etanercept. (a-c) Miapaca-2 tumor-bearing mice were treated with $1 \mathrm{mg} / \mathrm{kg}$ of GEM or vehicle (saline) i.p. every day for 6 days, starting from day 10 after tumor inoculation. JP1400 or vehicle (saline), $3 \mathrm{mg} / \mathrm{kg}$, was i.v. administered every other day for three times, starting from day 11 after tumor inoculation. ETC or vehicle (saline), $5 \mathrm{mg} / \mathrm{kg}$, was i.p. given every other day for five times, starting from day 7 after tumor inoculation. Tumor growth curve was shown in $\mathbf{a}$ and $\mathbf{b}$ as mean + S.E.M. and tumor weight at day 22 was shown in $\mathbf{c}$. (d) Model of synergism between Smac mimetic and chemotherapy agents

TNF- $\alpha$ production and massive cell loss; ${ }^{12,13,15}$ in class II cells, Smac mimetic still induces autocrine TNF- $\alpha$ production but this does not have a major effect on the cell population; and in class III cells, Smac mimetic has no effect on autocrine TNF- $\alpha$ production or on cell death. The ability of cells to produce TNF- $\alpha$ is necessary but not sufficient for Smac mimetic to induce cell death as a single agent. In class II cells, although autocrine-TNF- $\alpha$ production, RIP1-dependent caspase-8 complex formation and caspase-3 activation were induced by Smac mimetics, only marginal cell death was detected in these cells. As Smac mimetic/TNF- $\alpha$ signaling does not inhibit the cell cycle, it is critical that the cell death signal is strong enough to ensure massive cell death. Otherwise the surviving cells could continue to grow and compensate for the cell loss. Consistent with this notion, Smac mimetic does slightly enhance the cell proliferation rate, which was partially blocked in the presence of z-VAD (Figure 2), suggesting that the increased cell growth may in part be a consequence of Smac mimetic-induced caspase activation and cell death. The mechanism behind this phenomenon warrants further investigation.

The extent of autocrine TNF- $\alpha$ induction and the relative levels of pro-apoptotic versus antiapoptotic proteins in different cells may distinguish class I versus class II cells. Use of Smac mimetics in combination with chemotherapy agents could convert at least some of the class II cells into sensitive cells. Enhanced Smac mimetic cell killing in combination with standard chemotherapeutics relies heavily on their ability to (1) inhibit cellular proliferation and (2) activate the canonical NF- $\kappa$ B pathway to exacerbate the production of TNF- $\alpha$, thus enhancing the extrinsic cell death pathway (Figure 6d). Surprisingly, the mitochondria-dependent, intrinsic apoptotic pathway initiated by genotoxics seems to be less important in this combination effect. Pretreatment of cells with either anti-TNF- $\alpha$ antibodies or RIP1 siRNA almost completely blocked Smac mimetic/ chemotherapy agent-induced cell death.

Both extrinsic and intrinsic determinants are critical for cancer cell survival and death. ${ }^{19}$ Moreover, it has been suggested that all cancer cells have the capability to undergo apoptosis, but are prevented from doing so by signals from both neighboring cells and the tumor microenvironment. ${ }^{20}$ The observation that chemotherapeutics can greatly enhance the level of $\mathrm{TNF}-\alpha$ production in combination with Smac mimetics has many promising possibilities in itself. Strong induction of TNF- $\alpha$ localized to the tumor could mimic immunotherapy-based studies that show that high localized TNF- $\alpha$ reduces blood flow and causes tumor vasculature damage. ${ }^{21}$ TNF- $\alpha$ may also modulate the immune response within the tumor by stimulating macrophage and NK cell 
activity. Synthesis of TNF- $\alpha$ by inflammatory cells in grade III invasive breast cancer patients correlated with fewer cases of recurrence and metastasis. ${ }^{22}$ On the other hand, it is unclear how much TNF- $\alpha$ is required to overcome the survival threshold and induce apoptosis.

Different from Smac mimetic, which induces TNF- $\alpha$ production through activation of the noncanonical NF- $\kappa \mathrm{B}$ pathway, ${ }^{12,13}$ chemotherapeutics can activate the canonical $\mathrm{NF}-\kappa \mathrm{B}$ pathway to enhance TNF- $\alpha$ production and death receptor-induced cell death. The ability of cells to produce TNF- $\alpha$, but not clAP2, in response to JP1400 correlates very well with its sensitivity to JP1400/chemotherapy combination. Understanding the mechanism of this differential response could provide a predictive biomarker for Smac mimetic therapy. We have found that for all cell lines tested, Smac mimetics clearly induce clAP degradation and subsequent processing of NF- $\kappa \mathrm{B}$ p100 (data not shown). Thus, the NF- $\kappa \mathrm{B}$ nuclear translocation, the post-translational modifications of $\mathrm{NF}-\kappa \mathrm{B}$ including acetylation and phosphorylation, or epigenetic modifications and chromatin structure of the target gene promoter are more likely to determine the specific gene response in different cell lines. This question continues to provide an exciting area of future research in the use of Smac mimetics.

It is noteworthy that the Miapaca-2 cell line used in these studies is not sensitive to Smac mimetics alone in vitro, yet becomes sensitized to JP1400 in in vivo tumor xenograft models. Autocrine/paracrine TNF- $\alpha$ could be highly concentrated in the compact tumor microenvironment, which may lead to the enhanced Smac mimetic activity in vivo. Alternatively, the tumor microenvironment is complex and there might be other factors that contribute to Smac mimeticinduced cell death in tumors that are not recapitulated in cell culture systems. This finding highlights the potential that many more tumors might be sensitive to Smac mimetics as a single agent in vivo.

The observation that the mechanism of action of Smac mimetics alone or in combination with chemotherapy agents, in xenograft models, is at least partially dependent upon autocrine TNF- $\alpha$ is to the best of our knowledge the first documented report. Why the soluble TNF receptor, etanercept, was not able to fully block Smac mimetic or Smac mimetic/gemcitabine-induced tumor cell killing is not fully clear, but it may in fact be a result of the inability of etanercept to penetrate compact tumors. In addition, the compact tumor cell environment may lead to quick engagement of newly synthesized TNF- $\alpha$ with its receptor in an autocrine or paracrine manner, even before etanercept has had a chance to neutralize its action. Alternatively, etanercept is reported to preferentially bind soluble TNF- $\alpha$ over membrane-bound TNF $-\alpha .^{23}$ Again, in a compact tumor microenvironment, cleavage of soluble TNF- $\alpha$ may not be necessary as membrane-bound TNF- $\alpha$ could directly bind and engage neighboring TNF receptors. On the other hand, it is not clear and also difficult to determine the pharmacokinetics of etanercept in the animal body and how this relates to its ability to counteract all the autocrine TNF- $\alpha$ action induced by Smac mimetic. Lastly, we cannot rule out the possibility that other factors may have a critical role in Smac mimetic-induced cell death in vivo. Further in vivo studies are warranted to fully understand the mechanistic and clinical effect of Smac mimetic-induced tumor regression and cell killing.

The above results suggest that combination therapy of conventional chemotherapeutics in conjugation with a smallmolecule Smac mimetic offers a promising strategy for the treatment of cancer. The efficacy of such treatments will be, in part, dependent upon intrinsic TNF- $\alpha$ levels or the ability of the Smac mimetic/chemotherapy combination to induce TNF- $\alpha$, providing a potential predictive and clinically measurable biomarker.

\section{Materials and Methods}

Reagents. Pan-caspase inhibitor, z-VAD-FMK, was purchased from Biomol (Plymouth Meeting, PA, USA). Caspase substrates, Ac-DEVD-AMC, Ac-LEHDAMC and IKK inhibitor IV, were obtained from Calbiochem (Gibbstown, NJ, USA). Cytochrome $c$, dATP, saline and SN38 were purchased from Sigma (St Louis, MO, USA) . Cisplatin was obtained from LC Laboratories (Woburn, MA, USA). Etoposide and 5-FU were obtained from LKT Laboratory (St Paul, MN, USA). Gemcitabine and paclitaxel were obtained from Polymed Therapeutics (Houston, TX, USA). ERK and NF- $\kappa$ B p 65 antibodies were obtained from Cell Signaling (Danvers, MA, USA), and Histone $\mathrm{H} 3$ antibody was obtained from Abcam (Cambridge, MA, USA). All the other antibodies used in this study were previously described. ${ }^{14}$ Etanercept was generously provided by Dr. Sherri Zhu.

Recombinant proteins. Recombinant Apaf- 1 and pro-caspase- 9 protein was kindly provided by Dr. Xiaodong Wang from UT Southwestern Medical Center at Dallas, TX, USA. GST-XIAP was generated as previously described. ${ }^{24}$ Active caspase- 3 was generated using baculovirus-expressing pro-caspase $-3^{25}$ that, when expressed in Sf21 insect cells for $>24 \mathrm{~h}$, autocleaved itself into active caspase-3. Active caspase-3 was purified using Ni-NTA agarose (Qiagen, Valencia, CA, USA) and Hitrap Q column (Amersham Biosciences, Piscataway, NJ, USA).

Caspase-3 and caspase-9 de-repression assays. For caspase- 3 assays, a final volume of $30 \mu \mathrm{l}$ was assembled on ice, including $3 \mu \mathrm{l}$ of $10 \times$ caspase assay buffer ( $300 \mathrm{mM}$ HEPES, $\mathrm{pH} 7.5,1 \mathrm{M} \mathrm{NaCl}, 50 \%$ sucrose, $1 \%$ CHAPS, $200 \mathrm{mM} \beta$-mercaptoethanol and $20 \mathrm{mg} / \mathrm{ml} \mathrm{BSA}),{ }^{25} 0.5 \mathrm{nM}$ GST-XIAP and $0.3 \mu \mathrm{l}$ caspase-3 substrate (Ac-DEVD-AMC, $1 \mathrm{mM}$ ). The mixture was incubated at $30^{\circ} \mathrm{C}$ for $10 \mathrm{~min}$ in the presence of $5 \mu \mathrm{l} \mathrm{Smac}$ mimetics and then supplemented with $5 \mu \mathrm{l}$ of $0.25 \mathrm{nM}$ caspase- 3 to initiate the enzyme reaction. Fluorescent signal was measured using an automated spectrophotometer (Pherastar, BMG Labtech, Cary, NC, USA) at wavelengths of $350 / 460 \mathrm{~nm}$ (excitation/emission). For caspase-9 assays, $5 \mu \mathrm{l}$ of Smac mimetics and $10 \mu \mathrm{l}$ of a master mix was added each well, which included $50 \mathrm{nM}$ Apaf-1, $200 \mathrm{nM}$ cytochrome $c, 10 \mu \mathrm{M}$ dATP, $20 \mathrm{nM}$ GSTXIAP, $100 \times$ caspase-9 substrate (Ac-LEHD-AMC, $1 \mathrm{mM}$ ) and buffer A ( $20 \mathrm{mM}$ Tris (pH 7.4), $150 \mathrm{mM} \mathrm{NaCl}, 1 \mathrm{mM}$ EDTA, $1 \mathrm{mM}$ EGTA and $1 \mathrm{mM} \mathrm{DTT}$ ) with $0.2 \%$ CHAPS. Additional controls contained wells with no dATP or GST-XIAP. The plate was incubated at $30^{\circ} \mathrm{C}$ for $10 \mathrm{~min}$ and then the reaction was initiated by the addition of $5 \mu \mathrm{l} 2.5 \mu \mathrm{M}$ pro-caspase- 9 ( $20 \mathrm{nM}$ final). The fluorescence reading was carried out as described for the caspase- 3 assay.

Cell lines and cell viability assays. All cell lines except HCC461 were obtained from ATCC (Manassas, VA, USA). Cell lines A2058, BT474, G361, HT-29, Miapaca-2 and PANC-1 were cultured in DMEM (Hyclone, Waltham, MA, USA) supplemented with $10 \%$ FBS. HCC461, MDA-MB435, NCl-H226, NCI-H460 and PC-3 cells were cultured in RPMI-1640 (Hyclone) supplemented with 10\% FBS. Cell viability assays were carried out as previously described. ${ }^{14}$

BrdU cell proliferation assays. A2058 cells were seeded at 3000 cells/well in 96-well assay plates for $16-24 \mathrm{~h}$. Cells were treated as indicated in the figure legends for another $24 \mathrm{~h}$, followed by a 24-h labeling with BrdU reagent. BrdU incorporation was determined with a BrdU Cell Proliferation Assay Kit (Calbiochem) as per the manufacturer's instructions.

Preparation of cell lysates and caspase-8 immunoprecipitation. After the indicated treatment, cell pellet was collected and lysed in Buffer A (20 mM Hepes (pH 7.4), $10 \mathrm{mM} \mathrm{KCl}, 1.5 \mathrm{mM} \mathrm{MgCl} 2,1 \mathrm{mM}$ EDTA, $1 \mathrm{mM}$ EGTA and $1 \mathrm{mM}$ DTT) with $1 \%$ TX-100 and Complete protease inhibitor 
cocktail (Roche, Indianapolis, IN, USA) and then incubated on ice for $20 \mathrm{~min}$. Lysates were then cleared by centrifugation at 14000 r.p.m. for $30 \mathrm{~min}$. The soluble fraction was kept and protein concentration determined by Bradford assay (Thermo Scientific, Waltham, MA, USA). The procedure for caspase- 8 immunoprecipitation was described previously. ${ }^{14}$

siRNA transfection. Luciferase and RIP1 siRNAs were synthesized at Dharmacon (Lafayette, CO, USA). Luciferase target sequences were as follows: 5'-AACGTACGCGGAATACTTCGA-3'; RIP1 target sequence: 5'-CCACTA GTCTGACGGATAA-3'. siRNA or Dharma-Fect Duo (Dharmacon) were diluted in Opti-MEM medium (Invitrogen, Carlsbad, CA, USA) and transfected as suggested by Dharmacon.

ELISA analysis of plasma autocrine human TNF- $\alpha$ secretion. Blood samples were collected through jugular exsanguination. Plasma was separated by centrifugation of blood samples in lithium heparin plasma microtainer tubes (BD, San Jose, CA, USA) according to the manufacturer's protocol. Samples were kept at $-80^{\circ} \mathrm{C}$ until ready for use. ELISA was performed using a quantitative high sensitivity sandwich immunoassay from R\&D Systems (Minneapolis, MN, USA) (Human TNF- $\alpha / T N F S F 1 A$ Quantikine HS ELISA, HSTA00D) as per the manufacturer's instructions.

RNA preparation, reverse transcription and real-time PCR. Total RNA was isolated using TRIzol Reagent (Invitrogen). RNA $(1 \mu \mathrm{g})$ was reversed transcribed with Superscript II kit (Invitrogen) using the manufacturer's suggested guidelines. Real-time PCR was performed on an Applied Biosystems (Foster City, CA, USA) $7900 \mathrm{HT}$ real-time PCR machine with SYBR green technology. Primers for real-time PCR of CDNA were synthesized by IDT (Coralville, IA, USA) and are as follows: TNF- $\alpha$ forward (5'-GCAGGTCTACTTTGGGATCATTG- $\left.3^{\prime}\right)$, TNF- $\alpha$ reverse (5'-GCGTTTGGGAAGGTTGGA-3'), CIAP2 forward (5'-CAAAGCATTGAAGTC TGCAGTTG-3'), cIAP2 reverse (5'-GCAAGCATGGTTTCCTGGAT-3'), cyclophilin forward (5'-TGCCATCGCCAAGGAGTAG- $\left.3^{\prime}\right)$ and cyclophilin reverse (5'-TG CACAGACGGTCACTCAAA- $3^{\prime}$ ). Real-time PCR cycling parameters were $50^{\circ} \mathrm{C}$ for $2 \mathrm{~min}, 95^{\circ} \mathrm{C}$ for $10 \mathrm{~min}$, followed by 40 cycles of $95^{\circ} \mathrm{C}$ for $15 \mathrm{~s}$ and $60^{\circ} \mathrm{C}$ for $1 \mathrm{~min}$ each. TNF- $\alpha$ and clAP2 data were normalized for expression with cyclophilin, and results were expressed as fold induction over untreated cells.

Preparation of nuclear and cytosol fractions. A2058 cells were plated in $10 \mathrm{~cm}$ dishes and treated as indicated. Cell pellets were resuspended in $400 \mu \mathrm{l}$ of Buffer A with protease inhibitor. After $15 \mathrm{~min}$ of incubation on ice, $25 \mu \mathrm{l}$ of $10 \%$ NP-40 was added and the samples were vortexed vigorously. After centrifugation at $3000 \times g$ for $10 \mathrm{~min}$ at $4^{\circ} \mathrm{C}$, the supernatant was saved as cytosol fraction. The pellet was washed once with Buffer $A$ and was further resuspended in $75 \mu$ lof Buffer $B$ (Buffer A with $5 \%$ glycerol and $400 \mathrm{mM} \mathrm{NaCl}$ ). Samples were incubated on ice for $30 \mathrm{~min}$ and centrifuged at $10000 \times g$ for $5 \mathrm{~min}$ at $4^{\circ} \mathrm{C}$. The supernatant was saved as the nuclear faction.

In Vivo HCC461 and Miapaca-2 xenograft models. Female athymic nude-Foxnlnu (Harlan) mice, 5 to 6 weeks old, were injected subcutaneously with $1 \times 10^{7}$ HCC461 or Miapaca-2 cells. After 6 to 7 days, when tumors had reached $\sim 200 \mathrm{~mm}^{3}$, mice were randomized into treatment groups of eight mice per group for the tumor growth experiments. As for the TNF- $\alpha$ ELISA and tumor RNA extraction experiment, animals were randomized into treatment groups of five mice per group when tumors had reached $\sim 500 \mathrm{~mm}^{3}$. JP1400 or vehicle (saline) was i.v. administered in a total volume of $200 \mu \mathrm{l}$. Gemcitabine, etanercept or vehicle (saline) was i.p. injected in a total volume of $200 \mu \mathrm{l}$. The dose used for each drug is shown in the figure legend. Tumors were measured twice a week with vernier calipers. Tumor volumes were calculated according to (length $\times$ width $\left.^{2}\right) / 2$. All animal experiments were performed according to the OLAW and USDA guidelines and under an approved IACUC use protocol.
Statistical analysis. Results were analyzed for statistical significance using the unpaired two-tailed Student's t-test (Graphpad, La Jolla, CA, USA).

\section{Conflict of interest}

We disclose that Dr. John Minna is supported by the $\mathrm{NCl}$.

Acknowledgements. We thank Drs. Xiaodong Wang and Sherri Zhu for providing useful reagents. We also thank Drs. Rolf Brekken and Sean Petersen for their critical reading of the paper. JDM was supported by the NCI SPORE P50CA70907, DOD Prospect.

1. Gorlick R, Bertino J. Drug Resistance in colon cancer. Semin Oncol 1999; 26: 606-611.

2. Weinstein IB. Cancer. Addiction to oncogenes-the Achilles heal of cancer. Science 2002; 297: 63-64.

3. Fesik SW. Promoting apoptosis as a strategy for cancer drug discovery. Nat Rev Cancer 2005; 5: 876-885.

4. Los M, Burek CJ, Stroh C, Benedyk K, Hug H, Mackiewicz A. Anticancer drugs of tomorrow: apoptotic pathways as targets for drug design. Drug Discov Today 2003; 8: 67-77.

5. Du C, Fang M, Li Y, Li L, Wang X. Smac, a mitochondrial protein that promotes cytochrome c-dependent caspase activation by eliminating IAP inhibition. Cell 2000; 102: 33-42.

6. Zhou H, Li Y, Liu X, Wang X. An APAF-1, cytochrome c multimeric complex is a functional apoptosome that activates procaspase-9. J Biol Chem 1999; 274: 11549-11556.

7. Verhagen $A$, Coulson E, Vaux DL. Inhibitor or apoptosis proteins and their relatives: IAPS and other BIRPS. Genome Biol 2001; 2: 3009.

8. Ashkenazi A, Dixit V. Death Receptors: signaling and modulation. Science 1998; 281: $1305-1308$.

9. Li L, Thomas RM, Suzuki H, De Brabander JK, Wang X, Harran PG. A small molecule Smac mimic potentiates TRAIL- and TNFalpha-mediated cell death. Science 2004; 305: $1471-1474$.

10. Galban S, Hwang C, Rumble JM, Oetjen KA, Wright CW, Boudreault A et al. Cytoprotective effects of IAPs revealed by a small molecule antagonist. Biochem J 2009; 417: 765-771.

11. Sun H, Nikolovska-Coleska Z, Lu J, Qiu S, Yang CY, Gao W et al. Design, synthesis, and evaluation of a potent, cell-permeable, conformationally constrained second mitochondria derived activator of caspase (Smac) mimetic. J Med Chem 2006; 49: 7916-7920.

12. Varfolomeev E, Blankenship JW, Wayson SM, Fedorova AV, Kayagaki N, Garg P et al. IAP antagonists induce autoubiquitination of c-IAPs, NF-kappaB activation, and TNFalphadependent apoptosis. Cell 2007; 131: 669-681.

13. Vince JE, Wong WW, Khan N, Feltham R, Chau D, Ahmed AU et al. IAP antagonists target clAP1 to induce TNFalpha-dependent apoptosis. Cell 2007; 131: 682-693.

14. Wang $L$, Du F, Wang $X$. TNF-a induces two distinct caspase-8 activation pathways. Cell 2008; 133: 693-703

15. Petersen SL, Wang L, Yalcin-Chin A, Li L, Peyton M, Minna J et al. Autocrine TNFalpha signaling renders human cancer cells susceptible to Smac-mimetic-induced apoptosis. Cancer Cell 2007; 12: 445-456.

16. Lu J, Bai L, Sun H, Nikolovska-Coleska Z, McEachern D, Qiu S et al. SM-164: a novel, bivalent $\mathrm{Smac}$ mimetic that induces apoptosis and tumor regression by concurrent removal of the blockade of cIAP-1/2 and XIAP. Cancer Res 2008; 68: 9384-9393.

17. Janssens S, Tschopp J. Signals from within: the DNA-damage-induced NF-kB response. Cell Death Differ 2006; 13: 773-784.

18. Brzoskz K, Szumiel I. Signaling loops and linear pathways: NF-kB activation in response to genotoxic stress. Mutagenesis 2009; 24: 1-8.

19. Hickman J. Apoptosis and chemotherapy resistance. Eur J Cancer 1996; 32A: 921-926.

20. Raff M. Social controls on cell survival and cell death. Nature 1993; 356: 397-400.

21. Kaufman H, Wolchok J. General Principles of Tumor Immunotherapy. Sprinter: Dordrecht, The Netherlands, 2007.

22. Estevam FR, Augusto SF, Rodrigues SA, Pinheiro MR, Monteiro AF. Apoptosis and production of TNF-alpha by tumor-associated inflammatory cells in histological grade III breast cancer. Cancer Immunol Immunother 2005; 54: 671-676.

23. Keane J. TNF-blocking agents and tuberculosis: new drugs illuminate an old topic Rheumatology (Oxford) 2005; 44: 714-720.

24. Yang QH, Du C. Smac/DIABLO selectively reduces the levels of CIAP1 and CIAP2 but not that of XIAP and livin in HeLa cells. J Biol Chem 2004; 279: 16963-16970.

25. Gao Z, Tian Y, Wang J, Yin Q, Wu H, Li YM et al. A dimeric Smac/DIABLO peptide directly relieves caspase-3 inhibition by XIAP. J Biol Chem 2007; 282: 30718-30727.

Supplementary Information accompanies the paper on Cell Death and Differentiation website (http://www.nature.com/cdd) 